\title{
BIOACCUMULATION OF HEAVY METALS IN THAIS SPP OBTAINED FROM THE NIGER DELTA REGION OF NIGERIA AND ASSOCIATED HEALTH RISKS DUE TO CONSUMPTION
}

'Aniekan I., ${ }^{2}$ Moslen M., and ${ }^{3}$ Onwuteaka, J.N.

${ }^{123}$ Department of Animal and Environmental Biology, Rivers State University, PMB 5080, Port Harcourt, Nigeria.

email: moslen4c@yahoo.com

\begin{abstract}
Heavy metal concentrations were assessed in Thais spp obtained from four stations in Bakana (RVS1 and 2) and Ikang (CRS1 and 2) of the Niger Delta. Fifty samples were collected from each station for six months from October 2018 to March 2019. The Atomic Absorption Spectrophotometric method was used for analysis of heavy metals. Mean metal concentrations in Thais spp at Ikang and Bakana were as follows: Cr:CRS I =4.03, CRS2=3.82, RVS1=4.21, RVS2 $=4.038, \mathrm{Cd}: \mathrm{CRS} 1=0.78, \mathrm{CRS} 2=0.57, \quad \mathrm{RVS} 1=0.86, \quad \mathrm{RVS} 2=0.73$, $\mathrm{Pb}: \mathrm{CRS} 1=4.64, \mathrm{CRS} 2=3.62, \mathrm{RVS} 1=5.88, \mathrm{RVS} 2=4.83, \mathrm{Zn}: \mathrm{CRS} 1=26.46, \quad \mathrm{CRS} 2=21.34, \quad \mathrm{RVS1}: 38.77$, RVS2 $=37.43, \mathrm{Cu}: \mathrm{CRS} 1=14.96, \mathrm{CRS} 2=18.39, \mathrm{RVS} 1=31.45, \mathrm{RVS} 2=31.86, \mathrm{Fe}: \mathrm{CRS} 1: 103.86, \mathrm{CRS} 2=100$. $18, R V S 1=132.42, \mathrm{RVS} 2=129.24$. Health risk assessment was also carried out to evaluate the estimated daily intake, hazard quotient (carcinogenic and non-carcinogenic) and hazard index. The concentrations of five heavy metals were also compared with WHO permissible limit and were all higher except Zn. Estimated Daily Intake values were lower than the reference oral doses of the respective metals indicating low risk. THQ, HQ and Hazard index (carcinogenic and non-carcinogenic) for all stations were $<1$ indicating minimal health risk to consumers of Thais spp contaminated with heavy metals in the study area. This study thereby concluded that Thais spp obtained from Ikang and Bakana areas of the Niger Delta is safe for consumption.
\end{abstract}




\section{INTRODUCTION}

The rapid development of industries and agriculture has resulted in increasing pollution by heavy metals, which are a significant environmental hazard for invertebrates, fish, and humans (Uluturhan and Kucuksezgin, 2007). Pollution is the altering of the environment by activities of man, by addition of substances partially or wholly which will result in an imbalance and hence have deleterious effect on the living organisms including man (Sunder,1988). The sea and other water bodies are receptacles for the wastes being generated by industries and humans that live near rivers, sea animals are always part of the organisms endangered and have the potential to accumulate these poisonous wastes like heavy metals (Paul and James, 2011). Used oil and other petroleum products are also deposited in drainages and washed down the sea and rivers as runoffs (Johnson,2008). The Niger Delta is located in the southern part of Nigeria and plays host to several oil exploring companies and manufacturing industries. It also accommodates Petrochemical, refining and fertilizer industries (Akpila, 2006) which implies that the region is prone to pollution.

Heavy metal pollution is one of the challenges of coastal waters as a result of human activities such as oil exploration and exploitation, construction and fabrication of marine boats, disposal of industrial and domestic wastes and sailing (Moslen and Miebaka, 2016). Pollution of aquatic ecosystems by heavy metals is an important environmental problem, as they constitute some of the most dangerous toxicants that can be bioaccumulated in living tissues (Guo, et al., 1997; Omoregie et al., 2002). Otitoju and Otitoju, (2013) stated that heavy metal pollution of terrestrial and aquatic environments in Niger Delta region of Nigeria is on the increase due to increased urbanization and crude oil exploration. Inhabitants of areas where the source of sea fish is highly polluted by heavy metals are at risk in terms of consumption (Ombretta, et al., 2017). Calderon, et al., (2003) and Powers, et al., (2003) had also stated that dietary intake of toxic elements is the main route of exposure for most people, so when these pollutants find their way into the water bodies, sea organisms or aquatic organisms ingest them either in the cause of feeding or respiration and these toxicants remain within the body until man harvests them for consumption and end up ingesting these metals and the health implications associated with the consumption of these metals is deleterious. Copat, et al., (2012) also found out that fish raised in contaminated waters take up heavy metals in large quantities enough to cause potential health risks to the consumers. Heavy metals have been reported to exert negative effect on biological processes in general and may influence the nutritional and biological status of sea foods (Udosen, et al., 2001). Regularly discharged pollutants have imminent detrimental effect on the flora and fauna of coastal ecosystems especially mangrove ecosystems and tropical mudflats (Ansari, et al., 2014). Many aquatic organisms for example Thais spp have the ability to accumulate 
and biomagnify contaminants like heavy metals in the environment (Davies et al., 2006) therefore monitoring programs and investigations on the existence of heavy metals in marine water environments have increased significantly due to alarms over the accumulation of contaminants and toxic effects in marine organisms and to humans over the food chain (Otchere, 2003). Thais spp (Lamarch, 1816) commonly known as Rock Shell is a mollusc and class of gastropods with a humped or spined, thick-walled shell, mostly with short whorls with the shell closed by a honey operculum. They are up to $5 \mathrm{~cm}$ in length and are dirty grey to brown in colour. The aperture is red and the lip toothed (Avil and Ross, 1999). They are salt water molluscs, found on rocks and mussel banks and exhibit both restricted geographical and local distribution (Davis and Fitzgerald, 2004). Thais spp locally called Nkonko in efik is an important source of cheap protein for the coastal people of southeast Nigeria, its fisheries supports a thriving, but subsistent economic activity. After consuming their soft-flesh, the empty shells are constantly thrown away as waste (Malu et al., 2009). They are deposit feeders and bioindicators of heavy metal and hydrocarbon pollution in the aquatic environment. Deposit feeding has to do with sediment and benthic dwellers, this implies that the organism has the ability to bioaccumulate heavy metals in its tissues in the process of deposit-feeding and so integrate the environmental conditions of the water and sediment over time (Moslen and Miebaka 2017).

The ultimate discharge of effluents by industries and other anthropogenic activities in and around creeks and rivers constitute a major environmental problem particularly in developing areas such as the Niger Delta in Nigeria (Moslen and Daka, 2016). Therefore, this study intended to evaluate concentrations of heavy metals in Thais spp and attendant health implication associated with consumption within some areas of the Niger Delta.

\section{MATERIALS AND METHODS Study site description}

The study sites for this work were Bakana and Ikang in the Niger Delta region of Nigeria (Figure 1). Bakana area is characterized by mangrove swamp forest with mangrove species like Rhizophora spp, Avicennia species, Nipa palm. Anthropogenic activities within the area includes artisanal fishing, lumbering, hunting and sometimes bunkering. Ikang is on the eastern flank of the Niger Delta and also characterized by mangrove swamp forest with activities such as building of local boats, occasional transport of illegally refined petroleum products and fishing 


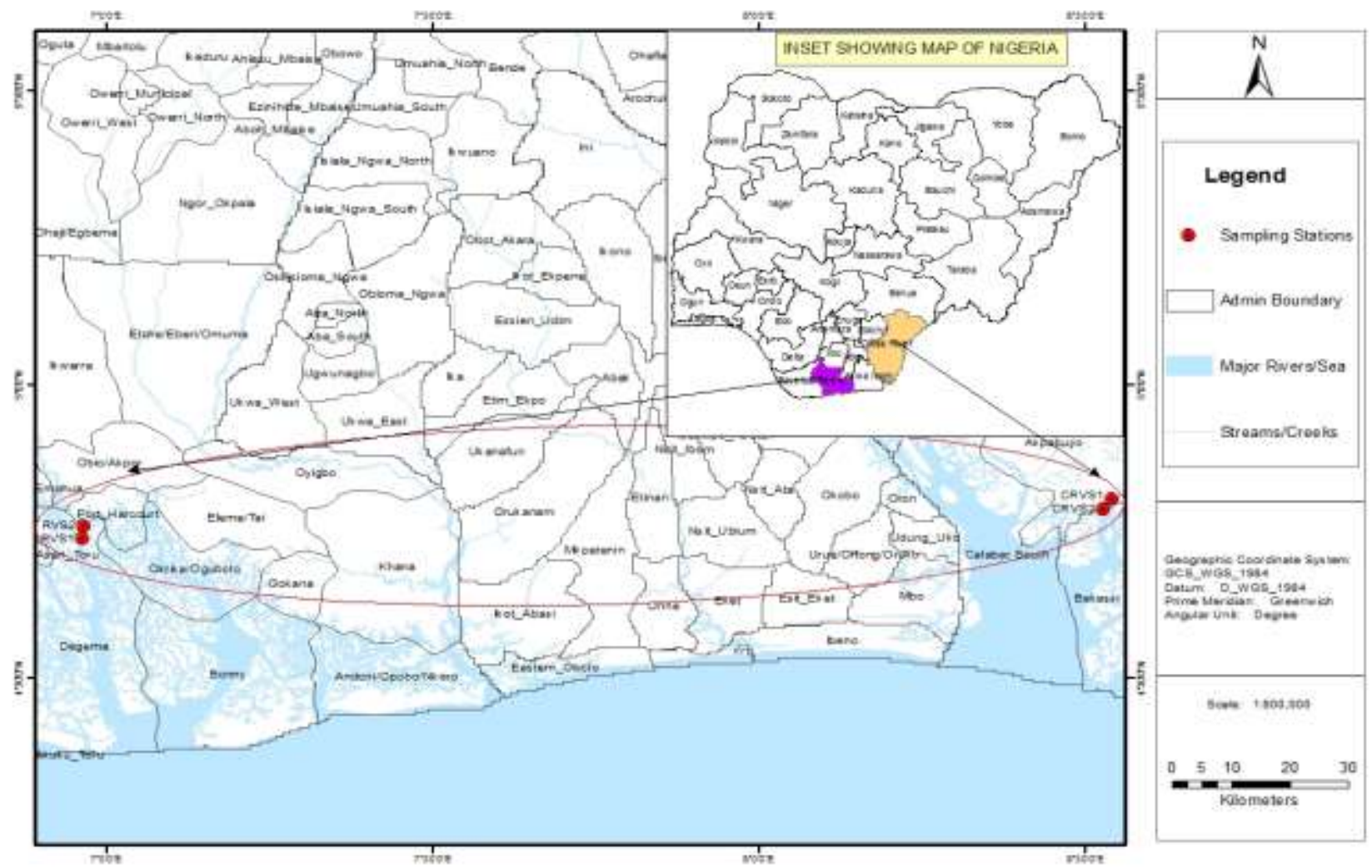

study site with sampled points

Figure1:

\section{SAMPLE COLLECTION}

Samples were collected from two different stations in each site. Fifty samples of Thais spp were randomly collected from each station, washed and put in well labeled plastic containers. The samples were collected by handpicking at the intertidal mudflats. All samples were preserved in ice-packed coolers while in transit before laboratory analysis.

\section{SAMPLE ANALYSIS}

\section{Sample preparation for heavy metals}

Samples were removed from their shell with a clean acid washed stainless steel needle and dried in the oven to constant weight at $80^{\circ} \mathrm{C}$ for two days in a clean acid washed petridish., After drying, grinding of the samples to fine powders with a porcelain mortar and pestle was done. Platinum dish was cleaned, dried, ignited and covered at $500^{\circ} \mathrm{C}$ for 30 minutes in the furnace, dish was allowed to cool and covered in a desiccator and weighed until a constant weight was obtained. Four grams of the sample was weighed, samples were ashed in the furnace to a build up of $500^{\circ} \mathrm{C}$, the cover was slightly opened for escape of gases, it was checked periodically for complete ashing and later brought down to cool (Moslen and Miebaka, 2017).

\section{Digestion for heavy metals}

$5 \mathrm{ml} / 10 \% \mathrm{HCL}$ and $5 \mathrm{ml} / 10 \%$ nitric acid were added to the sample, it was then poured into a beaker and placed on a hot plate and digested to near dryness, then it was brought out to cool off. It was transferred quantitatively using a stirring rod and through a funnel and filter paper into a clean dry $20 \mathrm{ml}$ standard volumetric flask with $20 \mathrm{ml}$ of deionized water, the filtrates were collected with clean acidwashed and appropriately labeled $30 \mathrm{ml}$ plastic containers for aspiration on presentation to the Atomic Absorption 
Spectrophotometer (AAS-Model 210VGP BUCK SCIENTIFIC,USA) (MMAF,2005). Then the concentration of $\mathrm{Cr}, \mathrm{Cd}, \mathrm{Fe}, \mathrm{Zn}, \mathrm{Pb}$, $\mathrm{Cu}$ were determined as it displayed on the computer connected to the AAS.

\section{STATISTICS}

Analysis of variance was done using the General linear model in order to detect significant differences in the concentration of heavy metals in the tissues of whelk between the stations examined. The software package Minitab 16 was used for the analysis.

\section{Health Risk Analysis}

Health risk assessment was done and the following were calculated: Estimated daily intake (EDI), Target Hazard Quotient (THQ) (non-carcinogenic), Hazard Quotient (HQ) "(carcinogenic) and Hazard Index (HI),

$$
\begin{aligned}
E D I= & =\frac{E_{F} \times E_{D} \times F_{I R} \times C_{F} \times C_{M} \times 10^{-3}}{W_{A B} \times T_{A}} \\
& \text { as used by Moslen and }
\end{aligned}
$$

Miebaka, (2017)

Where $E_{\mathrm{F}}$ : exposure frequency, (365days)

$$
E_{D} \text { : exposure duration, (65years) }
$$

FiR: fresh food Ingestion rate(48g/person/day)(Ali and Hau, 2001)

$C_{F}:$ conversion factor $=0.208$

$\mathrm{C}_{\mathrm{M}}$ : heavy metal concentration in food stuffs $(\mathrm{mg} / \mathrm{kg}$ dry weight

\section{$W_{A B}$ : average body weight $(60 \mathrm{~kg})$}

$T_{A}:\left(E_{F} X E_{D}\right)$ is the average exposure of time for non- carcinogens (Wang et al., 2005).

Estimated Daily Intake (EDI) was used to determine the carcinogenic (THQ) and non-carcinogenic risk (HQ).

$$
\text { - } T H Q=\frac{E D I}{\text { RFDO }}
$$$$
\text { - } \mathrm{HQ}=\mathrm{EDI} \times \mathrm{SF}
$$

Where RFDO is the Reference oral dose and $\mathrm{SF}$ is slope factor (Moslen and Miebaka, 2017)

$$
\text { - } H \mathrm{H}=\Sigma H Q
$$

Hazard Index estimates the total risk from multiple contaminant pathways, it was determined by summing the HQs of the contaminant pathway (Moslen and Miebaka, 2017).

\section{RESULTS}

The summary results for heavy metals and WHO maximum limit is presented in Table 1. The mean concentration was highest in RVSI and lowest in CRVS 2 for $\mathrm{Fe}, \mathrm{Cr}, \mathrm{Cd}$, $\mathrm{Pb}$ and $\mathrm{Zn}$ with mean values $(\mathrm{mg} / \mathrm{kg})$ ranging from 100.18-132.42, 3.82-4.21, $0.57-0.86, \quad 3.62-5.88$ and 21.34-38.77 respectively. The mean concentration for Cu was highest at RVS2 $(31.86 \mathrm{mg} / \mathrm{kg})$ and lowest in CRVS1 (14.96 mg/kg). Analysis of variance showed significant difference $(p<0.05)$ between periods and no significant difference $(p>0.05)$ between stations sampled. The concentration of all heavy metals were higher than WHO maximum limit except $\mathrm{Zn}$ (Table 1). The estimated daily intake for $\mathrm{Pb}, \mathrm{Cd}, \mathrm{Cr}, \mathrm{Zn}$, $\mathrm{Cu}, \mathrm{Fe}$, is presented in Table 2 while Target Hazard Quotient (noncarcinogenic) is presented in Table 3 and Hazard Quotient (carcinogenic) is given in Table 4. The hazard index for carcinogenic and non-carcinogenic risk is shown in Table 5 with the following observations. HI for carcinogenic risks $C R 1=0.00034, C R 2=0.00035, R \vee S 1=0.00049$, RVS2 $=0.00038$, with values below 1 . Hazard index for non-carcinogenic risk gave: $C R 1=0.667, C R 2=0.59, \quad R V S 1-=0.84$ and RVS2 $=0.76$. 
Table 1: Mean Concentration of Heavy Metals with WHO Permissible Limit (mg/kg).

\begin{tabular}{|l|l|l|l|l|l|l|}
\hline & CR1 & CR2 & RVS1 & RVS2 & WHO 1993 & $\begin{array}{l}\text { WHO } \\
\mathbf{2 0 1 1}\end{array}$ \\
\hline $\mathrm{CR}$ & 4.031 & 3.82 & 4.21 & 4.038 & 0.05 & - \\
\hline $\mathrm{Cd}$ & 0.78 & 0.57 & 0.86 & 0.73 & 0.10 & - \\
\hline $\mathrm{Pb}$ & 4.64 & 3.62 & 5.88 & 4.83 & 0.30 & - \\
\hline $\mathrm{Zn}$ & 26.48 & 21.34 & 38.77 & 37.43 & 50 & - \\
\hline $\mathrm{Cu}$ & 14.96 & 18.39 & 31.45 & 31.86 & 10 & - \\
\hline $\mathrm{Fe}$ & 103.86 & 100.18 & 132.42 & 129.24 & - & 43 \\
\hline
\end{tabular}

Table 2: Estimated daily intake of heavy metals $(\mathrm{mg} / \mathrm{kg})$

\begin{tabular}{|l|c|c|c|c|}
\hline \multicolumn{1}{|c|}{ Metals } & CR1 & CR2 & RV1 & RV2 \\
\hline $\mathrm{Cd}$ & 0.000129 & 0.000094 & 0.000143 & 0.00012 \\
\hline $\mathrm{Pb}$ & 0.00077 & 0.00060 & 0.000978 & 0.000825 \\
\hline $\mathrm{Cr}$ & 0.00067 & 0.000635 & 0.00070 & 0.00067 \\
\hline $\mathrm{Cu}$ & 0.0024 & 0.00306 & 0.0052 & 0.0053 \\
\hline $\mathrm{Zn}$ & 0.0044 & 0.0035 & 0.0064 & 0.0062 \\
\hline $\mathrm{Fe}$ & 0.017 & 0.0166 & 0.02 & 0.02 \\
\hline
\end{tabular}

Table 3: Target Hazard Quotient of Heavy Metals

\begin{tabular}{|l|c|c|c|c|}
\hline \multicolumn{1}{|c|}{ Metals } & CR1 & CR2 & RV1 & RV2 \\
\hline $\mathrm{Cd}$ & 0.129 & 0.094 & 0.143 & 0.12 \\
\hline $\mathrm{Pb}$ & 0.22 & 0.17 & 0.279 & 0.235 \\
\hline $\mathrm{Cr}$ & 0.22 & 0.21 & 0.23 & 0.22 \\
\hline $\mathrm{Cu}$ & 0.064 & 0.080 & 0.140 & 0.14 \\
\hline $\mathrm{Zn}$ & 0.014 & 0.011 & 0.02 & 0.02 \\
\hline $\mathrm{Fe}$ & 0.02 & 0.02 & 0.028 & 0.028 \\
\hline
\end{tabular}

Table 4: Hazard Quotient of Heavy Metals

\begin{tabular}{|l|c|c|c|c|}
\hline \multicolumn{1}{|c|}{ Metals } & CR1 & CR2 & RV1 & RV2 \\
\hline $\mathrm{Cd}$ & 0.000049 & 0.000036 & 0.000054 & 0.000046 \\
\hline $\mathrm{Pb}$ & 0.0000065 & 0.0000051 & 0.0000083 & 0.0000070 \\
\hline $\mathrm{Cr}$ & 0.00335 & 0.00031 & 0.00035 & 0.00033 \\
\hline $\mathrm{Cu}$ & NA & NA & NA & NA \\
\hline
\end{tabular}




\begin{tabular}{|l|l|l|l|l|}
\hline $\mathrm{Zn}$ & NA & NA & NA & NA \\
\hline $\mathrm{Fe}$ & NA & NA & NA & NA \\
\hline
\end{tabular}

$\mathrm{NA}=$ not available

Table 5 : Hazard Index of heavy metals at study stations

\begin{tabular}{|l|l|l|l|l|}
\hline & CRVS1 & CRVS2 & RVS1 & RVS2 \\
\hline nNon-carcinogenic risk & $\mathbf{0 . 6 6 7}$ & $\mathbf{0 . 5 9}$ & $\mathbf{0 . 8 4}$ & $\mathbf{0 . 7 6}$ \\
\hline Carcinogenic risk & $\mathbf{0 . 0 0 3 4}$ & $\mathbf{0 . 0 0 0 3 5}$ & $\mathbf{0 . 0 0 0 4 9}$ & $\mathbf{0 . 0 0 0 3 8}$ \\
\hline
\end{tabular}

\section{Discussion}

Thais spp is a relevant source of protein and the rate at which it is gradually becoming scarce in the Niger Delta region is very alarming hence there is need for regular monitoring. In this study there was significant variation in the concentration of heavy metals between months $(P<0.05)$ but no significant difference between stations, which implies that there is a change in concentration with time, and the anthropogenic activities that result in the concentration of these contaminants within Bakana and lkang occur at different rates with time. The levels of concentration of heavy metals in this study followed this trend $\mathrm{Fe}>\mathrm{Zn}>\mathrm{Cu}>\mathrm{Pb}>\mathrm{Cr}>\mathrm{Cd}$ for $\mathrm{CRl}$ with $\mathrm{Fe}$ having the highest concentration of $132.42 \mathrm{mg} / \mathrm{kg}$, this agrees with the work of Moslen and Miebaka in (2017) on heavy metals bioaccumulation in a named gastropod in the Niger Delta, where Fe had the highest concentration. The mean concentration of metals in the tissues of Thais spp were higher in this study $(\mathrm{Fe}=103.86 \mathrm{mg} / \mathrm{kg}, \quad \mathrm{Pb}=4.64 \mathrm{mg} / \mathrm{kg}$, $\mathrm{Cd}=0.78 \mathrm{mg} / \mathrm{kg}$,

$\mathrm{Cu}=14.96 \mathrm{mg} / \mathrm{kg}, \mathrm{Cr}=4.03 \mathrm{mg} / \mathrm{kg}$ and $\mathrm{Zn}=26.48 \mathrm{mg} / \mathrm{kg}$ ) when compared to concentrations of $\mathrm{Fe}, \mathrm{Pb}, \mathrm{Cd}, \mathrm{Cu}, \mathrm{Cr}$ and $\mathrm{Zn}$ in a study done by Eze and Ogbuehi (
2015). The concentration of $\mathrm{Cr}$ had its mean value above the WHO maximum level of $0.05 \mathrm{mg} / \mathrm{kg}$ across all four stations which is in line with a study done by Piotr, et al. (2014) where mean value for $\mathrm{Cr}$ was $0.69 \mathrm{mg} / \mathrm{kg}$ above WHO maximum level suggesting exposure risk. Exposure to chromium may result in severe respiratory, cardiovascular,

gastrointestinal, haematological, hepatic, renal, and neurological effects leading to death (ATSDR, 2008).

$\mathrm{Cd}$ concentration also has its mean value above WHO maximum level of 0.10 $\mathrm{mg} / \mathrm{kg}$ across all four stations, this agrees with the study conducted by Kouakou, ef al. (2016) where the least Cd concentration level (4.59) was higher than WHO permissible limit. This indicates potential risk to consumers of Thais spp within the vicinity. Nwadinigwe, et al. (2014) opined that $\mathrm{Cd}$ is a non-essential metal and when it enters the body it is capable of remaining there and cause severe damage to the system. $\mathrm{Pb}$ concentration also had its mean value higher than the WHO maximum limit of $0.30 \mathrm{mg} / \mathrm{kg}$ for all four stations, Kamaruddin et al. (2018) reported $\mathrm{Pb}$ having the following values in $\mathrm{C}$. obtusa: $3.802 \mathrm{mg} / \mathrm{kg}$,

$4.909 \mathrm{mg} / \mathrm{kg}$,

$2.355 \mathrm{mg} / \mathrm{kg}$ which are higher than the WHO maximum limit. Akinrotimi et al. (2019) also reported $\mathrm{Pb}$ in Thais coronata 
with these value $(0.33 \mathrm{mg} / \mathrm{kg})$ still higher than the WHO maximum limit of 0.30 $\mathrm{mg} / \mathrm{kg}$. This implies that residents in this region who consume Thais spp may be predisposed to health risk due to $\mathrm{Pb}$. Monisha, et al. (2014) had said that $\mathrm{Pb}$ is a very toxic metal and that its widespread use has resulted to environmental degradation and health implications. For $\mathrm{Cu}$ the mean concentrations in all four stations were higher than the WHO permissible limit of $10 \mathrm{mg} / \mathrm{kg}$. The concentrations in this study were higher than concentrations reported by Ajiboye, et al. (2011) for Upeneus vittatus, Anchovilla commersonii, Pomadasys maculates, Lutjanus adetii, Ambassis commersoni with values of $0.009 \mathrm{mg} / \mathrm{kg}, 0.014 \mathrm{mg} / \mathrm{kg}$, $0.008 \mathrm{mg} / \mathrm{kg}, 0.008 \mathrm{mg} / \mathrm{kg}, 0.006 \mathrm{mg} / \mathrm{kg}$ respectively. The mean concentration of Fe was also above the WHO permissible limit of $43 \mathrm{mg} / \mathrm{kg}$ which is in tandem with the work of Tiimub and Mercy (2013) where concentration of $\mathrm{Fe}(49 \mathrm{mg} / \mathrm{kg})$ was higher than WHO maximum limit. Excess amount of $\mathrm{Fe}$ causesrapid increase in pulse rate and coagulation of blood in blood vessels, hypertension and drowsiness (Davies et al.,2006). ANOVA and Turkey Test showed that there was significant difference between periods (months) $\quad(P<0.05)$ and no significant difference between stations in the concentration of heavy metals. This variation with time, is an indication of influence of anthropogenic activities that occur at different rate in different times. This variation agrees with the study of Nsikak et al. (2007) where monthly variations were significantly different in the concentrations. The estimated daily intake of heavy metals were seen to be lower than the reference oral dose indicating low risk. THQ for all stations were $<1$, indicating low risk of heavy metals of non-carcinogenic origin. The $T H Q$ in this study agrees with the findings of Moslen and Miebaka (2017). THQ of heavy metals in this study also agrees with the findings of Tao et al., (2012) and Taweel et al. (2013) but disagrees with the findings of Krishna et al. (2014) who reported $\mathrm{THQ}$ (non-carcinogenic) for $\mathrm{Pb}$ and $\mathrm{Cr}$ to be $>1$ in fish from the coast of India. The hazard quotient for $\mathrm{Cd}, \mathrm{Cr}, \mathrm{Pb}$ in this study were $<1$, indicating minimal carcinogenic risk upon human exposure to $\mathrm{Cd}, \mathrm{Cr}$ and $\mathrm{Pb}$ in the study region. Generally, $\mathrm{HQ}<1$ indicates no carcinogenic health risk to humans exposed to $\mathrm{Cr}, \mathrm{Cd}$ and $\mathrm{Pb}$. Hazard Index for Carcinogenic risk across all stations were $<1$, indicating minimal carcinogenic risk of exposure through consumption of Thais spp in the study region. Hazard Index for noncarcinogenic risk value for all stations were $<1$ indicating minimal health risk of non-carcinogenic origin. ,Guerra, et al. (2012) said that non-carcinogenic impacts may occur in the residents when $\mathrm{HI}>1$, while the exposed person is unexpected to experience evident harmful health effects when $\mathrm{HI}<1$. Oyibo et al. (2018) opined that exposed populations are prone to experience health risk if the THQ value is equal to or greater than 1. HI in this study agrees with Ali, et al.(2019) in a study of carcinogenic and non-carcinogenic health risk assessment of some contaminants in Khorramabad, Iran, where HI values where $<1$, this findings agree with Moslen and Miebaka ( 2017) were HI were less than 1(0.64), it also agrees with the work of Patrick, et al. (2018) in Delta State, Nigeria and Malakotian et al. (2016) 
were $\mathrm{HI}$ values were less than 1 which poses no serious health concern within that area .

\section{CONCLUSION}

The concentration of Heavy metals in Thais spp in the study areas varied significantly across months and it means that the sources of these contaminants increase or decrease at different times. Heavy metals concentration were generally above WHO recommended limit but health risk assessment indicated values safe for consumption of the sea food (Thais spp) in the study region.

\section{REFERENCES}

Abdou, H.M. and Hassan, M.A. (2014). Protective role of omega-3 polyunsaturated fatty acid against lead acetate-induced toxicity in liver and kidney of female rats. Biology of Medical Research International PMC free article. PubMed.

Adeyemi, O.G., Adediran, G.O.and Oyeniyi,T. (1996). Some trace elements concentration in a variety of fishes from Asa River, llorin, Nigeria. Bioscience Research Communications 8 (2), 1996, 99102.

Agency for Toxic Substances and Disease Registry (ATSDR) (1995). Toxicological profile for Polycyclic Aromatic Hydrocarbons (PAHs)(Report). Atlanta, GA: U.S. Department of Health and Human Services, Public Health Service. Retrieved 2015-05-06.
Al-Busaid, M., Yesudhason, P., Al-Mughairi, S., Al-Rahbi, W. A., Al-Harthy, K. S., Al-Mazrroei, N. A., Al-Habsi, S. H. (2011). Toxic metals in commercial marine fish in Oman with reference to national and international standards, chemosphere, 85 (1), 67 -73 .

Ajiboye, O.O., Yakubu, A.F., Adams, T.E. (2011). A review of polycyclic aromatic hydrocarbons and heavy metal contamination of Fish from fish farms. Nigeria institute for oceanography and MARINE RESEARCH ,Sapele, Delta State, Nigeria. Journal of Applied Science and Environmental Management .vol.15(1)235-238.

Akoto,O., Bismark, E.F., Darko,G. and Adei, E. (2014). Concentrations and Health Risk Assessments of Heavy Metals in Fish from the Fosu Lagoon. International Journal for Environmental Research, 8(2), 40341.

Akter, A., Islam, M. M., Mondal, S. I., Mahmud, Z., Jewel, N. A., Ferdous, S., Amin, M. R. (2014). Computational identification of mRNA and targets from expressed sequences tags off coffee. Sandi Journal of Biological Sciences. $21(1), 3-12$.

Al-Busaidi, M., Yesudhason, P., AlMughairi, S., Al-Rahbi, W.A.K., AlMazrooei,N.A., Al-Habsi, S.H. (2011). Toxic metals in commercial marine fish in Oman with reference to national and international standards, Chemosphere, (85), 6773 
Al-Hossainy, A.E., Mohamed, F.S.M., Hassan, M.M., Abd Allah, (2012). Determination of cadmium and lead in perch fish samples by different pulse anodic stripping voltammetry and furnace atomic absorption spectrometry, Arabic Journal for Chemistry , 15(20) 19-31.

Ali, A. M., Ahmad, Z., Saba, M., Afshin, G., Yalda, H., Mohammad, H. S., Abdolazim, A., Mahmood, Y., Nasrin, $H$. And Mansour, G.(2019).Department of Environmental Health Engineering, Neyshabur University of Medical sciences, Neyshbar,Iran. Methodx. (6):1642-1651.

American Association of Rail Roads (1997).Risk Management Division, comparison of analytical methods for use in evaluating the risk from petroleum hydrocarbons in soil, prepared by Remediation Technologies, Inc. R-903.

Ashraf, W. and Mian, A.(2008).Total Petroleum Hydrocarbon (TPH)Burden in fish tissues from the Arabian Gulf. Available at http://www.pmu.edu.sa/Attachme nts/About /PDF/Research_Papers /Total\% $20 \quad$ Petroleum\%20 Hydrocarbon_Natural_Sciences.pdf

Atic, T., Ahiska, J. Attindog, A. Aydin, D. (2008). Ecological effects of some heavy metals ( $\mathrm{Cd}, \mathrm{Pb}, \mathrm{Hg}, \mathrm{Cr}$ ) pollution of phytoplanktonic alga and zooplantonic organisms in Sanyar Dam Reservoir in Turkey. African Journal for Biotechnology, (7), 1972 - 1977.
Agency for Toxic Substances and Disease Registry (ATSDR) (2011). Environmental Medicine; Environmentasl Health Education. "Toxicity of Polycyclic Aromatic Hydrocarbons (PAHs): Health Effects Associated With $\mathrm{PAH}$ Exposure"..

Avil, B. and Ros., M. (1999). Man and Mollusc, uses of shell bearing mollusc-past, present and future doubles, Day Company, New York, $4-7$.

Begum, A., Harikrishna, S., Khan, I., (2009) .Analysis of Heavy metals in Water, Sediments and Fish samples of Madivala Lakes of Bangalore, Karnata: International Journal of Chemical Technology Research, V.1 (12), p. 245-249.

Bennett, D.H., Kastenberg, W.E., McKone, T.E. (1999). A multimedia, multiple pathway risk assessment of atrazine: The impact of age differentiated exposure including joint uncertainty and variability. Reliable Engineering System Safety. (63):185-98.

Bernard, A. (2008). Cadmium and its adverse effects on human health. Indian Journal of Medical Research, 128(4), $557-564$.

Boonsaner, M. (2006). Environmental toxicology (4th ed.). Nakhon Prathom: Silpakorn University Press.

Bostrom, C.E., Gerde, P., Hanberg, A., Jernstrom, B., Johansson, C., Kyrklund, T., Rannug, A., Tornqvist, M., Victorin, K., Westerholm, R. 
(2002). "Cancer risk assessment, indicators, and guidelines for polycyclic aromatic hydrocarbons in the ambient air". Environmental Health Perspectives. 110 (Suppl. 3): 451-488.

Boulubasi, I., Mejanelle, L., Pete, R., Fillaux, J., Lorre, A. and Point, V. (2006). Transport by sinking particles in the open Mediterranean sea: A 1 year sediment trap study: Marine Pollution Bulletin (52), $560-571$.

Calderon, J., Ortiz-Perez, D., Yanez, L.and Diaz-Barriga, F. (2003). Human exposure to metals. Pathways of exposure, biomarkers of effect, and host factors. Ecotoxicology on Environmental Safety (56), 93-103.

Calyun, S., Jiquan, Z., Quiyun, M. and Yanan, C.(2015).Human Health and Ecological Risk Assessment of 16 Polycyclic Aromatic Hydrocarbons in Drinking Source Water from a Large Mixed use Reservoir. International journal of Environmental Research and Public Health.(12),13956-13969.

CCME (Canadian Council of Ministers of the environment ) (1992). Canadian environmental quality guidelines for the protection of Aquatic life.

Cheevaporn, V. (2004). Analytical technique for environmental quality. Chonburi:

ChonburiKarnpim Press.

Chikae , M., Hatano, Y., Ikeda, R., Morita, Y., Hassan, Q., Tamiya, E.(2004). Effects of bis (2-ethylhexyl) phthalate and benzo[a]pyrene on the embryos of Japanese medaka (Oryziaslatipes). Environmental Toxicology and Pharmacology.16:141-145

Chji, K, Kim, S., Hong, G. and Chon, H. (2011). Distribution of heavy metals in the sediments of Smith Korean Harbors. Environmental Geochemical Health, 34(1): 71 - 82.

Copat, C., Bella, F., Castaing, M., Fallico, R., Sciacca, S. and Ferrante, M. (2012). Heavy metals concentrations in fish from sicily (Mediterranean Sea) and evaluation of possible health risks to consumers. Bulletin of Environmental Contamination and Toxicology, 88, 78-83.

Corsi, R. (1998). Environmental Risk Assessment. Department of Civil Engineering, The University of Texas at Austin, from http://www.crwr.utexas.edu/gis/gis env99/class/risk/leture/Lect4/Fate.h tml.

Davies, O.A, Allison, ME, Uyi, H.S. (2006). Bioaccumulation of heavy metals in water, sediment and Periwinkle (Tympanotonusfuscatusvar radula) from the Elechi Creek, Niger Delta. African Journal of Biotechnology. 5: 968-97

Davydova,S. (2005). Heavy metals as toxicants in big cities, Microchemistry Journal,(79), 133136.

Dhananjayan, V. and Muralidaran, S. (2012). Polycyclic Aromatic 
Hydrocarbons in various species of Fish from Mumbai Habour, India and their dietary Intake Concentration to Human. International journal of Oceanography, (2012):1-6.

Dural, M., Goksu, M.Z.L. and Ozak, A. A. (2007). Investigation of heavy metal levels in economically important fish species captured from the Tuzla Lagoon, 102, 415-421.

Edwards, G. (2002). Mosquitoes, DDT, and Human Health. 21st Century Science and Technology Magazine., from http://www.21stcenturysciencetec h.com/articles/Fall02/Mosquitoes.ht $\underline{\mathrm{ml}}$.

Enuneku, A.A., Ainerua, M., Erhunmwunse, N. O., Osakwe, O. E.(2015). Total Petroleum Hydrocarbons in organs of Commercially Available Fish, Trachurus trecae from Oliha Market, Benin City, Nigeria. Department of Environmental Management and Toxicology, Faculty of life sciences, University of Benin, Benin city, Nigeria. Ife journal of

$\begin{array}{lll}\text { science, } & \text { vol. } & 17, \text { no. } 2\end{array}$

European Union (2013), Commission Regulation (EU) 1272/2013,

European Union Commission Regulation (EU)European Union Commission Regulation (EU) No 1327/2014 of 12 December $2014 \quad$ Amending Regulation (EC) No 1881/2006 as Regards Maximum Levels of Polycyclic Aromatic Hydrocarbons
(PAHs) in Traditionally Smoked Meat and Meat Products and Traditionally Smoked Fish and Fishery Products.

Eze, S.O. And Ogbuehi, G.I. (2015). Assessment of heavy metals and polycyclic aromatic hydrocarbons concentration in some stockfish species sold in five major markets of Aba South, Abia State. European journal of Pure and Applied Chemistry, Nigeria. vol. 2 no.1.

Fairbrother, A., Lewis, M.A. and Menzer, R.E. (2001). Methods in Environmental Toxicology (4th ed.).Philadelphia: Taylor \& Francis.

Farombi, E. O., Adelowo, O. A., Ajimoko, Y. R. (2007). Biomarkers or oxidative stress and heavy metal levels as indicators of environmental pollution in African cat Fish (Clariasgariepinus) from Nigeria, Ogun river, Int. Journal Environmental Research and Public Health, 4, $158-165$.

Fitzpatrick, R., Cass, A. and Besz, W. (2008). Measurement of Redox Potential (Eh) in Periodically Waterlogged Viticultural Soils. Retrieved October 23, 2009, from http://natres.psu.ac.th/Link/SoilCon gress/bdd/symp35/2135-t.pdf.

FAO/WHO (2014).Food and Agriculture Organization/World Health Organization Evaluation of Certain Food Additives and Contaminants: Forty-first report of the Joint FAO/WHO Expert Committee on Food Additives. From: 
whalibdoc. who.int/trs/WHO TRS 83 7.pdf Accessed.

Forstner, U. and Wittmann, G.T.W. (1983). Metal pollution in the aquatic environment. Germany: SpringerVerlag Berlin Heidelberg. Gregor. Solubilization of lead in lake and reservoir sediments by NTA. Journal Environmental Science Technology. (6) 278-279.

Gobas, F.A. P.C.,Wilcockson, J.B., Russell, R. W. and Haffner, G. D.(1999).Mechanism of biomagnifications in fish under laboratory and field conditions. Environmental and Scientific Technology (33):133-141.

Green, J. and Trett, M. W. (1989). The fate and effects or oil in freshwater. Library of congress CIP data, Elsevier science publishers. London and New York 89 - 152.

Guerra, F., Trevizam, A.R., Muraoka, T., Marcante, N.C., Canniatti-Brazaca, S.G.(2012).Heavy metals in vegetables and potential risk for human health.Sci. Agric.(69):54-60.

Gulliver, J.S. (2007). Introduction to chemical transport in the environment. New York: Cambridge University Press. Trace element sorption by sediment and soils - sites and processes. In Symposium on molybdenum. Chappell, W., \& Petersen, K. (eds). Vol. 2 pp. 425-553.

Han, J. X., Shang, Q., Du, Y. (2009). Effect of environmental cadmium pollution on human health. 1(3), $159-166$.

Haritash, A. K., Kaushik, C. P. (2009). "Biodegradation aspects polycyclic aromatic hydrocarbons (PAHs): A review". Journal of Hazardous Materials. (169): 1-15.

Harmanescu, M., Alda, L.M., Bordean, D.M, Gogoasa, I., Gergen, I. (2011).Heavy Metals health risk assessment for population via consumption of vegetables grown in old mining area; a case study: Banat County, Romania. Chemistry Central Journal.(5):64.

Hayat, S., Javed, M., Razzao, S., (2007). Growth performance of metal stressed: Pakistan Vertinary Journal, V. 27(1),P.8-12.

Hylland, K. (2006)."Polycyclic aromatic hydrocarbon (PAH) ecotoxicology in marine ecosystems". Journal of Toxicology and Environmental Health, Part A. 69 (1-2): 109-123.

Irfan, M. Hayat, S., Ahmad, A., Alyemeni, M. N. (2013). Soil cadmium enrichment: Allocation and plant physiological manifestations, Saudi Journal of Biological Scence., 20(1), $1-10$.

Izah, S. C., Orufugu, L. A., Kigigha, L. T. (2016). A review of the quality of assessment MaliasDomesticaBorkh and Cucumis Sativus L. in Yenegoa Metropolis, Bayelsa State, Nigeria. Britian Journal of Applied Research, 1, $5-7$. 
Jaishankar, M.T., Tseten, N., Anbalagan, B.B., Mathew, C. and Beeregowda, K.N. (2014). Toxicity, mechanism and health effects of some heavy metals. Interdisciplinary Toxicology $7(2), 60-72$.

Javed, M.and Usmani, N. (2011). Accumulation of heavy metals in fishes: a human health concern. International Journal of Environmental Science, 2, 659-670.

Javed,M. and Usmani, N. (2012). Toxic effects of heavy metals (Cu, Ni, Fe $\mathrm{Co}, \mathrm{Mn}, \mathrm{Cr}, \mathrm{Zn})$ to the haematology of Mastacembelusarmatus thriving in Harduaganj Reservoir, Aligarh, India. Global Journal of Medical Research, 2012, 12:59-64.

Johnsen, A. R.; Wick, L. Y.; Harms, $H$. (2005). "Principles of microbial PAHdegradation in soil". Environmental Pollution. 133 (1): 71-84.

Jones, K.C., Jackson, A. and Johnson, A.E. (1992). Evidence of an increase in cadmium content of herbage since the 1860s. Environmental Science Technology, 26, 834-836.

Jørgensen, A.; Giessing, A. M. B.; Rasmussen, L. J.; Andersen, $O$. (2008)."Biotransformation

polycyclic aromatic hydrocarbons in marine polychaetes". Marine Environmental Research. 65 (2): $171-186$.

Kamaruddin, E., Budjono and Muhammad H. (2018). Heavy Metals in sea water, sediments, and Snail Biota collected from coastal waters of IndaragiriHilir Regency, Riau Province, Indonesia. Department of Fisheries and Marine Sciences, University of Riau, Tampan, Pekanbaru, Indonesia. Research and Reviews Journal of Ecology and Environmental Sciences.ISSN:2347-7830.

Kendall, R.J., Todd, A.A., Robert, J.B., Catherine, M.B., James, A.C., Lovis, A.C. (2002). Chapter 29: Ecotoxicology. New York: The McGraw-Hill Co., Inc. Retrieved November 23, 2009, from http://www.nsrl.ttu.edu/personnel/ RJBaker/Publications/295-

EcotoxicologyKendall\%20et\%20al2001.pdf. NU Science Journal 2010; 7(1): 1-11.

Khan, S., Cao, Q., Zheng, Y. M., Huang, Y. Z., and Zhu, Y. G. (2008). Health risks of heavy metals in contaminated soils and food crops irrigated with waste water in Beiding, China, Environmental pollution, Vol. 152, No. 3, pp, $686-692$.

Khayatzadeh, J. And Abbasi, E.(2010).Effects of heavy metals on Aquatic Animals. Department of Biology, Sciences Faculty, Islamic Azad University, Mashhad Branch, Mashhad, Iran. The International Applied Geological Congress, Department of geology, Islamic Azad University.

Kim, S.G., Park, D.K., Jang, S.W., Lee, J.S., Kim, S.S., Chung, M.H. (2008). Effects of dietary benzo[a]pyrene on growth and haematological parameters in juvenile rockfish (Sebastes schlegeli). Bulletin of 
Environmental Contamination and Toxicology.

Kouakou,A.R., Lovis,B.K., Benjamin, K.Y.,Albert, T. And Kopoin, A. (2016).Heavy metals in sediments and their transfer to Edible Molluscs. Journal of Applied Sciences, vol.16 :534-541.

Krishna,P.V.,Madhusudhana,

K.,Swaruparani and Srinivas,
D.(2014).Heavy Metals Concentration in Fish Mugil cephalus from Machilipatnam Coast and possible Health Risk of consumers. British Biotechnology Journal,4(2):126-135.

Li, Z. Feng, C. Guan, H., Ma, M.(2001). DDT, $P A H$ and $P C B$ in sediments from the intertidal zone of Bohai Sea and Yellow Sea. Mar. Poll. Bull.42: (2): 132-136.CrossRefGoogle Scholar.Marine Department of Hong Kong, (1997). Statistical Tables 1996.Government Printer, Hong Kong, 1-42.

Lindqvist, L, Block, M. (1995). Excretion of cadmium during moulting and metamorphosis in Tenebrio molitor (Coleoptera; Tenebrionidae). Comparative Biochemical Physiology 111: 325-328.

Ljung, K. (2001). Heavy metal discharge into Lake Victoria: a study of the Uganda cities of Kampala, Jinja and Entebbe. Master's thesis, Department of Soil Science, Swedish University of Agricultural Sciences.
Luckey, T. O., Venugopal, B. (1977). Introduction to heavy metal toxicity in mammals. In: physiologic and chemical basis for metal toxicity. Pringer, Bostom, $1-37$.

Malakootian, M., Mortazavi M.S. and Amadi, A (2016). Heavy Metals bioaccumulation in fish of southern Iran and risk assessment of fish consumption. Environmental Health Engineering and Management journal 3(2), 61-68.

Malu, S. P., Abara, A. E., Obochi, G. O., Ita, B. I. and Edem, C. A. (2009). Analysis of Egeria radiate and Thais Coronata shells as Alternative source of calcium for food industry in Nigeria. Pakistan Journal of Nutrition 8(7), 965 - 969.

Manual of Methods of Analysis of Foodsmetals (MMAF) (2005), Manual of Methods of Analysis of foods, Oils and Fats. Directorate General of Health Services, Ministry of Health and Family Welfare, Government of India, New Delhi. $114 \mathrm{pp}$.

Marias, A. D., Blackhurst, D. M. (2009). Do heavy metals counter the potential health benefits of wine? JEMOSA (14) 2, $77-79$.

Medeiros, P. M., Bicego, M. C., Castelas, R. M., Sossco, C./D., Fillman, G., Zambori, A. J. (2005). Natural and antrhopogeni hydrocarbon inputs to sediments of parts lagoon estuary, Brazil. Environments International Journal, 31, $77-87$.

Millisli, V. S., Servulo, E. L. C., Sobral, L. G. S., Carvalho, D. (2001). 
Bioremediation of crude oil-bearing soil: Evaluating the effect of rhamnolipid addition to soil toxicity and to crude oil biodegradation efficiency. School of chemistry, federal university of Riodejaneiro RJ-Brasil-CEP: 21941 - 590. Global NEST Journal, 11 (2), 181 - 188.

Ministry of Environment. (2002). Minamata disease the history and measures. Environmental Health Department, Ministry of Environment, Government of Japan. Retrieved October 10, 2009, from

http://www.env.go.jp/en/chemi/hs Iminamata2002/index.html.

Mohanty, M., Kumar, P. H. (2013). Effect of ion on chelate assisted hexavalent chromium mung bean seedlings (Vigna Radiating, WiczekVar K 851) during seedling growth. JSPB. $9(2), 232-241$.

Moles, A. and Norcoss, B. L. (1998). Effects of oil-laden sediments on growth and health of juvenile flat fishes. Journal of Fish Aquatic Science, 55, 605-610.

Mortimer, C.H. (1971). Chemical exchanges between sediments and water in the Great Lakes speculations on probable regulatory mechanisms. Limnol. Oceanogr., 16, 374-404. National Academy of Science. (1972). Lead: airborne lead in perspective. Washington, DC: National Academy of Science. Purdue University. (2008). Solubility product constant, Ksp. Purdue University. Retrieved August 29, 2009, from http://www.chem.purdue.edu/gch elp/howtosolveit/equilibrium/solubili ty_products.h tm.

Ratchamongkol Technology University. (2008). Chemical for engineer. Department of Physics, Faculty of Science, Ratchamongkol Technology University. Retrieved November 29, 2009, from http://www.rmutphysics.com/char ud/scibook/chemistry/unit4.pdf.

Moslen, M. and Miebaka, C. A., (2017). Concentration of Heavy Metals and Health Risk Assessment of Consumption of Fish (Sarotherodonmelanotheron) from an Estuarine Creek in the Niger Delta, Nigeria, IOSR Journal of Environmental Science, Toxicology and Food Technology. 11 (3), 68-73.

Moslen, M. and Miebaka, C.A. (2016). Temporal Variation of Heavy Metal Concentrations in Periophthalmus sp obtained from Azuabie Creek in the Upper Bonny Estuary, Nigeria, Current Studies in Comparative Education, Science and technology, 3(2) 2016,136-147.

Mutlu, A., Lee, B. K., Park, G. H. Yu, B. G., Lee, C. H. (2012). Long term concentrations of airborne cadmium in metropolitan cities in Korea and potential halth risks. Atmospheric Environment. 47, 164 173.

Nagajyoti, P.C., Lee, K. D. and Sreekanth, T.V.M. (2010). Heavy metals, occurrence and toxicity for plants: a review. Environmental Chemistry of Lettuce; 8(3), 2010,199-216. 
Nwadinigwe, C.A., Udo, G.J. and Nwadinigwe, A.O. (2014). Seasonal variations of heavy metals concentrations in sediment samples around major tributaries in Ibeno coastal area,Niger Delta ,Nigeria International Journal of Scientific and Technology Research 3(11):254-265.

NWaichi, E.O.N., ." Ntorgbo, S.A. (2016).Assessment of PAHs levels in some fish and seafood from different coastal waters in the Niger DeltaToxicology Reports. 3, 167-172

O'Clair, C. E., Shirley T. C. and Taggarf, S. J. (1996). Dispersion of adult cancer magister at Glacier Bay, Alaska: variation with spatial scale, sex and reproductive status, 209 227.

Oechere, F. A. (2003). Heavy metals concentrations and burden in the bivalves (Anadara Sendilia) Senilis, crassostreatulipa and pernaperna) from lagoons in Ghana; Model to describe mechanism of accumulation/excretion. African Journal of biotechnology, 2(9), 280 $-287$.

Osborn, S. G. (2011). Methane contamination of drinking water accompanying gas-well drilling and hydraulic fracturing, Proceedings of the National Academy of Sciences of the United States of America (PNAS). 108(20), $8172-8176$,

Otitoju, O. I. and Otitodu, G. T. O. (2013). Heavy metal concentrations in water, sediment and periwinkle
(Typansonusfuscatus)

samples harvested from the Niger Delta.

P.B. Tchounwou, A.K. Patlolla, J.A. Centeno Carcinogenic and systemic health effects associated with arsenic exposure-a critical review

P.B. Tchounwou, W.K. Ayensu, N. Ninashvilli, D. Sutton Environmental exposures to mercury and its toxicopathologic implications for public health, Environ. Toxicol., 8 (2003), pp. 149-175A.F. Public Health Service. U.S. Department of Health and Human Services, Atlanta, GA (2008)

Palm, L.M.N., Carboo, D., Yeboah, P.O., Quasie, W.J., Gorleku, M.A., Darko, A. (2011). Characterization of polycyclic aromatic hydrocarbons (PAHs) present in smoked fish from Ghana. Advance Journal for Food Science and Technology, 3(5):332338.

Patrick-Iwuanyanwu ,K. C. and Nwokeji, U.H.(2018). Potential Health Risk from Heavy Metals via Consumption of Leafy Vegetables in the Vicinity of Warri Refining and Petrochemical Company, Delta State, Nigeria. Department of Biochemistry, Faculty of Science, University of Port Harcourt, Rivers State, Nigeria. Annals of Biological sciences, 6(2):30-37.

Paul, W. And James O.,(2011).Impact of industrial effluents on water Quality of streams in Nakawa-Ntinda, Uganda. Makerere University Institute of Environment and Natural 
resources. Journal of Applied science and Environmental management, Vol.15 (2) 289-296.

Piotr, R., Przemyslaw, N., Piotr, K.and Barbara, P.(2014). Bioaccumulation of selected metals in Bivalves(Unionidae) and Phragmites australis inhabiting a municipal water reservoir. Environmental monitoring Assessment:186(5):3199-3212.

Powers, K.M., Smith-Weller,T., Franklin, G.M., Longstreth, W.T., Swanson, P.D.and Checkoway, H. (2003). Parkinson's disease risks associated with dietary iron, manganese, and other nutrient intakes. Neurology 60, 1761-1766.

Rahman, M.S., Molla, A.H., Saha, N., Rahman, A. (2012). Study on heavy metals and its risk assessment in some edible fishes from Bangshi River, Savar, Dhaka, Bangladesh Food Chemistry, 134, 1847-1854.

Ravindra, K., Sokhi, R.,Grieken, R. (2008)."Atmospheric polycyclic aromatic hydrocarbons: Source attribution, emission factors and regulation". Atmospheric Environment. 42 (13): 2895-2921.

Raymond, A. W. and Felix, O. E. (2011). Heavy metals in contaminated soil: A review of sources, Chemistry, risks and best available strategies for reined diation. Analytical Environment chemistry research group, Department of chemistry, Benue State University, Makurdi. ISRN Ecology, Volume 2011, Article ID 402647,
Renieri, E.A., Sfakianakis, D.G., Alegakis, A.A., Safenkova, I.V., Buha, A., Matovic, $\quad V_{\text {., }}$ Tzardi, M. Dzantiev,B.B., Divanach, P., Kentouri, M., Tsatsakis, A.M. (2017). Nonlinear response to waterborne cadmium exposure in zebrafish. An in vivo study. Environmental Research, 157, 173-181

Rocha, P.R., Reis-Henriques, M.A., Coimbra, J.(2000)Polycyclic aromatic hydrocarbons inhibit in vitro ovarian steroidogenesis in the flounder

(Platichthysflesus L.).Aquatic Toxicology;48:549-559

Rodriguez, L., Ruiz, E., Azcarate, J.A. and Rincon, J. (2008). Heavy metal distribution and chemical speciation in tailings and soils around a $\mathrm{Pb}-\mathrm{Zn}$ mine in Spain. Journal of Environmental Management, 90, 1106-1116.

Salako, S. G., Adekayeni, O. O., Adephite, A. A., Hammed, T. B. (2016). Determination of metals content of Alcohol and Non-alcoholic canned Drisiles consumed at Idiroko Border Town Ogun State, Nigeria. Britain Journal of Applied Science Technology, 12, $1-8$.

Scientific Committee on Foods of EC (SCF) European Commission, Health, and Consumer Protection Directorate-General.; Brussels: 2002. The Opinion of the Scientific Committee on Food on the Risk to Human Health of PAHs in Food. SCF/CS/CNTM/PAH/29 Final.

Shuai-Long, W., Xiang-Rong, X., Yu-Xin, S., Jinling, L. (2013). Heavy metal 
pollution in coastal areas of South China: A review in marine pollution bulletin.76(1-2):7-15.

Simon, J. and Sobieraj, J. (2006). Contributions of common sources of polycyclic aromatic hydrocarbons to soil contamination. Remediation Journal, Volume 16. 20089.

Sivaperumal, P., Sankar, T. V., Visovanathan Nair R. G. (2007). Heavy metals concentration in fish, shell fish and fish products from internal markets of India Visa-vis international standard. Food Chemistry, 102(2), 612-630.

Spakianakis, D. G., Elisavet, A. R., Kentour, M., Aristidis, M. T. (2015). Effect of heavy metals on fish larvae deformities. Literature in environmental research 137:246. Research Gafe Journal, 137.

Stominska, I., Jezierska, B., (2000). The effect of Heavy metals on post embryonic development of COMMON CARP, Cyprinuscarpio L., Archives of Polish Fisheries, Vol.8 Fasc.1 119-128.

Tao, Y.,Yuan, Z., Xaona, H. and Wei, M. (2012). Distribution and bioaccumulation of metals in aquatic organisms of different trophic levels and potential health risk assessment from TaihuLake ,China.Ecotoxicology of Environmental safety, 81,55-64.

Tani, F., Barrington, S. (2005) Zinc and copper uptake by plants under two transpiration rates, Part II.Buckwheat
(Fagopyrum esculentum L.)Environmental Pollution. 138:548.

Taweel, A.Shuaimi-othman, M., Ahmad, A.K.(2013). Assessment of heavy metals in Tilapia fish (Oreochromisniloticus)from the Langat River and Engineering Lake in Bangi, Malaysia, and Evaluation of the health risk from tilapia consumption, Ecotoxicology of Environmental safety, 93,45-51.

Tiimub, B.M. and Mercy, A., D.(2013). Determination ofselected heavy metals and Iron concentration in two common Fish species in Densu River at weja District in grater Accra Region of Ghana. American international journal of biology.1 (1):pp.45-55.

Tolosa, I., de Mora, S.J., Fowler, S.W., Villeneuve,J.P., Bartocci, j. and Cattini C. 2005. Aliphatic and Aromatic hydrocarbons in marine biota and coastal sediments from the Gulf of Oman, Marine Pollution Bulletin, 50:1619-1633,

Tongo, I. Ełor, EE, Ezemonye, LIN (2018). Human Health Risk Assessment of PAHs in Fish and Shellfish from Amariaria community, Bonny River, Nigeria. Laboratory of Ecotoxicology and Environmental Forensics, Department of Animal and Environmental Biology, Faculty of Science, University of Benin, Nigeria. Journal of Applied Science for Environmental Management. Vol.22(5) 731-736. 
Uchegbu, S. N. and Anierobi, C. M. (2002). Impact of oil activities on the environment of host communities: lessons for orientpetroleum resources, Anambra State, Nigeria proceeding of a National conference in infrastructural development and city management organized by Faculty of Environmental Sciences, Anambra State University, Ui, from $12^{\text {th }}$ to $14^{\text {th }}$ November, 2012.

UNEP, (2011). UNEP Ogoni land oil assessment reveals extent of environmental contamination and threats to human health, Abuja, Nigeria.

USEPA (1996). Test Method for the evaluation of solid wastes (SW-846) Method 3630C, "Silica Clean up and separation of petroleum wastes".

USEPA (2000). Guidance for assessing chemical contaminant. Data for use in fish advisories, fish sampling and analysis, $3^{\text {rd }}$ ed. Washington DC, office of water, 2000.

Valko, MMHCM, Morris, H., Crown, M. T. D., (2005). Metals, toxicity and oxidative stress. Curiculum forr Meical Chemistry 12(10), 1161 1208.

Van, T.C., Van C.A.M., Verweij R.A.(1996).Long-term toxicity of five polycyclic aromatic hydrocarbons for the terrestisl isopods Oniscusasellus and Porcellioscaber. Environmental Toxicology and Chemistry.15:1 199-1210.
Vane, C. H., Chenery, S. R., Harrison, I., Kim, A. W., Moss-Hayes, V., Jones, D. G. (2011). "Chemical signatures of the Anthropocene in the Clyde estuary, UK: sediment-hosted total petroleum

hydrocarbon, polyaromatic hydrocarbon and polychlorinated biphenyl pollution records". Philosophical Transactions of the Royal Society A: Mathematical, Physical and Engineering Sciences. 369 (1938): 1085-1111.

Vinodhini, R., Narayanan, M., 2009. The impact of toxic heavy metals on the haematological parameters in common CARP (Cyprinuscarpio):Iran. Journal for Environmental Health Science ., V. 6(1),P. 23-28.

Vuori, K. (1995). Direct and indirect effect of iron on river ecosystems. Furnish environment institute Helsinki, Uusimaa region, Finland, 32(3): 317 -329 .

Walker, C.H., Hopkin, S.P., Sibly, R.M. and Peakall, D.B. (2006). Principles of ecotoxicology (3rd ed.). New York: Taylor \& Francis.

Weldegebriel, Y., Chandravanshi, B.S, and Wondimu, T. (2012). Concentration levels of metals in vegetables grown in soils irrigated with river water in Addis Ababa, Ethiopia. Ecotoxicology and Environmental Safety, 77, 57-63.

Wessel, N., Rousseau S., Caisey, X. Quiniou, F., Akacha, F(2007). Investigating the relationship between embryotoxic and 
genotoxic effects of

benzo[a]pyrene, 17 [alpha]-

ethinylestradiol and endosulfan on

Crassostreagigas embryos. Aquatic Toxicology; 85:133-142.

Wilson, E.A., Powell, E.N., Wader, T.L.R.

Taylor, J., Presley, B.J., Brooks, J.M. (1992).

Spatial and Temporal distribution of

contaminant body and disease in the

Gulf of Mexico Oyster Populations

Heigolander Meeresunters., 46: 201-235. 